\title{
Pengaruh Pelatihan, Disiplin Kerja, Dan Budaya Organisasi Terhadap Komitmen Organisasi Pegawai PT. PLN (Persero) Area Tanjungpinang
}

\author{
Intan Maizah Ela Yani, Myrna Sofia, Nurhasanah
}

Fakultas Ekonomi Universitas Maritim Raja Ali Haji, Tanjungpinang, Kepulauan Riau, Indonesia

\begin{abstract}
ABSTRAK: Penelitian ini bertujuan untuk mengetahui pengaruh pelatihan, disiplin kerja dan budaya organisasi terhadap komitmen organisasi pegawai PT. PLN (Persero) Area Tanjungpinang. Metode penelitian yang digunakam yaitu metode statistic deskriptif dengan pendekatan bersifat kuantitatif. Teknik pengumpulan data dilakukan dengan cara observasi dan kuesioner. Jumlah sampel penelitian yang digunakan adalah 74 responden. Analisis data yang digunakan yaitu analisis regresi linier berganda, pengujian hipotesis dalam bentuk uji $\mathrm{T}$ dan uji F serta analisis koefisien determinasi. Penelitian yang dilakukan menghasilkan Pelatihan berpengaruh signifikan terhadap komitmen organisasi pegawai PT. PLN (Persero) Area Tanjungpinang karena nilai t hitung > ttabel atau $23.057>1,994$ dan nilai signifikansi yang dihasilkan 0,000 $<0,05$. Disiplin Kerja berpengaruh signifikan terhadap komitmen organisasi pegawai PT. PLN (Persero) Area Tanjungpinang karena nilai t hitung > ttabel atau 2,649 > 1,994 dan nilai signifikansi yang dihasilkan 0,010<0,05. Budaya Organisasi tidak berpengaruh terhadap komitmen organisasi pegawai PT. PLN (Persero) Area Tanjungpinang karena nilai t hitung $<$ t tabel atau -1.424 > 1,994 dan nilai signifikansi yang dihasilkan 0,159>0,05.
\end{abstract}

Kata Kunci: Pelatihan, Disiplin Kerja, Budaya Organisasi dan Komitmen Organisasi

\begin{abstract}
This study aims to determine the effect of training, work discipline and organizational culture on the organizational commitment of employees of PT. PLN (Persero) Tanjungpinang Area. The research method used is descriptive statistical method with a quantitative approach. Data collection techniques are carried out by observation and questionnaire. The number of research samples used was 74 respondents. Analysis of the data used is multiple linear regression analysis, hypothesis testing in the form of $T$ test and $F$ test and analysis of the coefficient of determination. The research conducted resulted in training having a significant effect on the organizational commitment of employees of PT. PLN (Persero) Tanjungpinang Area because the value of $t$ arithmetic $>t$ table or 23,057> 1,994 and the significance value produced 0,000<0,05. Work Discipline has a significant effect on the organizational commitment of employees of PT. PLN (Persero) Tanjungpinang Area because the value of $t$ count $>$ ttable or 2.649> 1.994 and the significance value produced $0.010<0.05$. Organizational culture does not affect the organizational commitment of employees of PT. PLN (Persero) Tanjungpinang Area because the value of t count $\langle t$ table or $-1.424>1.994$ and the significance value produced is $0.159>0.05$.
\end{abstract}

Keywords: Training, Work Discipline, Organizational Culture and Organizational Commitment

Email Address : intanmaizah@gmail.com 


\section{PENDAHULUAN}

Dalam persaingan usaha yang semakin meningkat, peran sumber daya manusia (SDM), yang dimiliki suatu perusahaan dirasakan semakin meningkat. Tidak dapat dipungkiri bahwa kompetensi pegawai dalam suatu perusahaan seringkali menjadi salah satu kunci keberhasilan, terutama bagi perusahaan yang bergerak dibidang jasa. Pentingnya peningkatan kompetensi pegawai yang terus menerus kemudian mendorong perusahaan memberikan pendidikan dan pelatihan/training agar pegawainya mampu untuk memahami setiap kebutuhan masyarakat atau konsumen secara tepat dan dapat menjadi kepuasan bagi masayrakat maupun konsumen. Untuk mempersiapkan sumber daya manusia tidak hanya dilihat dari segi kuantitasnya saja, sebab tersedianya sumber daya manusiayang cukup banyak belum tentu merupakan jaminan bahwa hasil yang dicapai efisien dan efektif.

Meskipun pelatihan tenaga kerja memerlukan biaya yang tidak sedikit tetapi pelatihan harus tetap dilaksanakan karena pelatihan tersebut mempunyai manfaat yang besar bagi perusahaan atau pegawai perusahaan. Manfaat bagi perusahaan antara lain adalah perusahaan mempunyai tenaga kerja yang siap melaksanakan pekerjaannya sehingga dengan adanya tenaga kerja yang demikian perusahaan dapat mencapai tujuannya dengan lebih mudah. Dengan dilaksanakanpelatihan diharapkan pegawai akan semakin mampu memahami dan melaksankan fungsinya.

Hal ini sejalan dengan pendapat Kamsir (2016:126), pelatihan merupakan proses untuk membentuk dan membekali karyawan dengan menambah keahlian, kemampuan, pengetahuan dan perilakunya. Jadi dari penjelasan diatas dapatdisimpulkan pelatihan akan membentuk perilaku karyawan yang sesuai dengan yang diharapkan perusahaan, misalnya sesuai dengan budaya perusahaan. Kemudian akan membekali karyawan dengan berbagai pengetahuan, kemampuan dan keahlian, sesuai dengan bidang pekerjaannya.Semua organisasi atau perusahaan pasti mempunyai standar perilaku yang harus dilakukan dalam hubungannya dengan pekerjaan, baik secara tertulis maupun tidak, dan mengiginkan para pegawai untuk mematuhinya sebagai upaya untuk meningkatkan produktivitas, tetapi dalam kenyataan sering terjadi pegawai sebagai manusia mempunyai kelemahan, diantaranya masalah kedisiplinan. Oleh karna itu, peningkatan disiplin menjadi bagian yang penting dalam manajemen sumber daya manusia, sebagai faktor penting dalam peningkatan produktivitas. Menurut Sutrisno (2012:85), disiplin pegawai yaitu dimana pun manusia berada, dibutuhkan peraturanperaturan dan ketentuan ketentuan yang akan mengatur dan membatasi setiap kegiatan dan perilakunya. Dalam penjelasan di atas jelas bahwa peraturan atau pun ketentuan adalah sesuatu yang harus ada untuk dipatuhi dan dilaksakan agar terbentuknya perusahaan yang bernilai tinggi dalam kedisiplinan.

Hal ini berarti budaya organisasi sangat diperlukan oleh setiap perusahaan yang perlu selalu dikembangkan dan disesuaikan dengan perubahan lingkungan organisasi. Budaya organisasi merupakan aspek yang sangat penting dalam suatu organisasi karena suatu organisasi atau perusahaan memiliki budaya organisasi sendiri yang berbeda dengan organisasi lainnya. Budaya organisasi dalam suatu perusahaan akan berjalan dengan baik apabila terus menurus dilakukan sosialisasi kepada pegawai. Lingkungan organisasi terdiri dari sumber daya manusia dengan latar belakang dan tingkah yang berbeda. Dengan demikian, perubahan budaya organisasi dilakukan terlebih dahulu melalui pengubahan pola pikir segenap sumber daya manusia didalam organisasi. Tantangan yang cukup komplek lainnya adalah mengubah budaya kerja lama yang tidak sesuai lagi dengan nilai- 
nilai budaya kerja baru pada seluruh pegawaisecara sukarela dan partisipasi pegawai secara sukarela.

Era globalisasi sekarang ini, menuntut Badan Usaha Milik Negara (BUMN) untuk meningkatkan pelayanan secara professional sesuai dengan bidangnya masing-masing. PT. PLN (Persero) adalah perusahaan BUMN di Indonesia yang bertugas menyuplai serta mengatur pasokan

listrik, begitu pula dengan PT.PLN (Persero) Area Tanjungpinang.PT. PLN (Persero) Area Tanjungpinang sebagai sebuah Badan Usaha Milik Negara (BUMN) yang secara umum memiliki tugas pokok maupun fungsi dalam melakukan kegiatan pelayanan kelistrikan kepada masyarakat secara menyeluruh. Jadi sudah jelas pelayanan yang diberikan adalah pelayanan yang benar-benar harus sesuai dengan keinginan dan kebutuhan masyarakat sehingga masyarakat dapat menikmati dan merasa puas terhadap pelayanan kelistrikan.

Peneliti berkesempatan untuk melakukan penilitian di PT.PLN (persero) Area Tanjungpinang. Jika ditelusuri lebih dalam banyak permasalahan yang ada, namun dalam kesempatan ini peneliti mengambil beberapa masalah sepertipelatihan, disiplin kerja, dan budaya organisasi terhadap komitmen organisasi pada pegawai yang ada di PT. PLN (Persero) Area Tanjungpinang.

Pelatihan kerja sesuatu yang wajib ada dalam sebuah perusahaan karena akan menunjang kemampuan maupun meningkatkan kualitas pegawai maupun meningkatkan kualitas sebuah perusahaan. Permasalahan pelatihan yang ada dalam perusahaan ini yaitu bagi pegawai yang sudah memiliki umur yang sudah tua tidak ingin lagi mengikuti pelatihan yang di rekomendasikan oleh kantor wilayah, karna merasa sudah tua dan mereka memilih untuk memberikan kesempatan bagi pegawaipegawai muda untuk mengikuti pelatihan.

Disiplin kerja berpengaruh kepada setiap orang yang ada dalam perusahaan, maka perlu ditetapkan disiplin kerja secara tertulis dan ada sanksi dari setiap pelanggaran yang dilakukan, serta kesadaran setiap pegawai dalam mendisiplinkan dirinya sendiri. Permasalahan disiplin dalam perusahaan ini masih ada pegawai yang terlambat datang bekerja walaupun sudah di tetapkan sistem absen menggunakan fingerprint. Kurangnya kesadaran untuk tepat waktu menjadikan ini sebuah permasalahan dan menarik peneliti untuk melakukan sebuah penelitian.

Budaya organisasi yaitu nilai-nilai ataupun aturan yang sudah ada dalam sebuah perusahaan sejak dulu. Budaya yang ada dalam perusahaan ini yaitu diadakannya sharing pagi sebelum melakukan pekerjaan serta diadakan nya sharing ilmu setiap jumat sore. Jadi dalam penelitian ini peneliti ingin meneliti apakah budaya yang ada di perusahaan ini sudah mampu menunjang kemajuan perusahaan.

Dalam permasalahan yang telah diuraikan diatas maka dalam penelitian ini dapat dilihat apakah setiap pegawai mempunyai komitmen terhadap perusahaan tempat ia bekerja, karena perusahaan membutuhkan orang-orang yang mempuyai loyalitas tinggi terhadap perusahaan. Dengan memiliki pegawai yang mempunyai sikap loyalitas terhadap organisasi maka dapat dikatakan perusahaa tersebut memiliki orang-orang yang memiliki keinginan pasti untuk mempertahankan keikutserataan dalam organisasi.

Berdasarkan latar belakang masalah tersebut peneliti tertarik untuk mengangkat topik ini dalam sebuah penelitiandengan judul "PengaruhPelatihan, Disiplin Kerja, dan Budaya Organisasi Terhadap Komitmen Organisasi Pegawai PT. PLN (Persero) Area Tanjungpinang".

\section{PERUMUSAN MASALAH}

Berdasarkan Uraian pada latar belakang di atas, maka dapatdirumuskan masalah penelitian adalah sebagai berikut :

1. Apakah Pelatihan berpengaruhterhadap Komitmen Organisasi Pegawai PT. PLN (Persero) Area Tanjungpinang?

2. Apakah Disiplin Kerja berpengaruhterhadap Komitmen Organisasi PegawaiPT. PLN (Persero) Area Tanjungpinang?

3. Apakah Budaya Organisasi berpengaruhterhadap Komitmen Organisasi Pegawai PT. PLN (Persero) Area Tanjungpinang?

4. Apakah Pelatihan, Disiplin Kerja, dan Budaya Organisasi berpengaruhterhadap 
Komitmen Organisasi Pegawai PT. PLN (Persero)Area Tanjungpinang?

\section{TUJUAN PENELITIAN}

Sesuai permasalahan diatas, maka tujuan penelitian adalah sebagaiberikut :

Untuk mengetahui pengaruhPelatihan secara parsial terhadapKomitmen

1. Organisasi Pegawai PT. PLN (Persero) Area Tanjungpinang.

2. Untuk mengetahui pengaruhDisiplin Kerja secara parsial terhadap Komitmen Organisasi Pegawai PT.PLN (Persero) Area Tanjungpinang.

3. Untuk mengetahui pengaruhBudaya Organisasi secara parsial terhadap Komitmen Organisasi Pegawai PT.PLN (Persero) Area Tanjungpinang.

4. Untuk mengetahui pengaruhPelatihan,Disiplin Kerja dan Budaya Organisasi secara parsial dan simultan terhadap Komitmen Organisasi Pegawai PT.PLN(Persero) Area Tanjungpinang.

\section{KAJIAN PUSTAKA}

\section{Pelatihan}

Menurut Kamsir (2016:126) pelatihan merupakan proses untuk membentuk dan membekali karyawan dengan menambah keahlian, kemampuan, pengetahuan dan perilakunya. Sedangkan menurut Sedarmayanti (2013:163) pelatihan dan pengembangan merupakan usaha mengurangi atau menghilangkan terjadinya kesenjangan antara kemampuan karyawan dengan yang dikehendaki organisasi.

\section{Disiplin Kerja}

Menurut Sutrisno (2012:97) disiplin kerja merupakan alat yang digunakan para manajer untuk berkomunikasi dengan karyawan agar mereka bersedia untuk mengubah suatu perilaku serta sebagai suatu upaya untuk meningkatkan kesadaran dan kesediaan seseorang menaati semua peraturan perusahaan dan norma-norma sosial yang berlaku.

\section{Budaya Organisasi}

Menurut Sopiah (2008:138) mengatakan bahwa budaya organisasi adalah sekumpulan nilai dan pola prilaku yang dipelajaridimiliki bersama oleh semua anggota organisasi dan diwariskan dari satu generasi ke generasi berikutnya.Sedangkan budaya organisasi menurut Fahmi (2013:47) adalah suatu kebiasaan yang telah berlangsung lama dan dipakai serta diterapkan dalam kehidupan aktivitas kerja sebagai salah satu pendorong untuk meningkatkan kualitas kerja para karyawan dan manajer perusahaan.

\section{HIPOTESIS}

Berdasarkan permasalahan dan kajian pustaka yang telah dikemukakan sebelumya, maka penulis merumuskan hipotesis sebagai berikut :

1. Pelatihan berpengaruh signifikan terhadap komitmen organisasi pegawai PT. PLN (Persero) Area Tanjungpinang.

2. Disiplin Kerja berpengaruh signifikan terhadap komitmen organisasi pegawai PT. PLN (Persero) Area Tanjungpinang.

3. Budaya Organisasi berpengaruh signifikan terhadap komitmen organisasi pegawai PT. PLN (Persero) Area Tanjungpinang.

4. Pelatihan, Disiplin Kerja, Budaya Organisasi, berpengaruh signifikan terhadap komitmen organisasi pegawai PT. PLN (Persero) Area Tanjungpinang.

5. Organisasi Pegawai PT. PLN (Persero) Area Tanjungpinang.

6. Untuk mengetahui pengaruhDisiplin Kerja secara parsial terhadap Komitmen Organisasi Pegawai PT.PLN (Persero) Area Tanjungpinang. 
7. Untuk mengetahui pengaruhBudaya Organisasi secara parsial terhadap

Komitmen Organisasi Pegawai PT.PLN (Persero) Area Tanjungpinang.

8. Untuk mengetahui pengaruhPelatihan,Disiplin Kerja dan Budaya Organisasi secara parsial dan simultan terhadap Komitmen Organisasi Pegawai PT.PLN(Persero) Area Tanjungpinang.

\section{METODOGI PENELITIAN}

Metode penelitian ini memakai metode penelitian kuantitatif. Metode penelitian kuantitatif adalah meode penelitian yang berlandaskan pada filsafat positivisme, digunakan untuk meneliti pada populasi atau sampel tertentu, teknik pengambilan sampel pada umumnya dilakukan secara random, pengumpulan data menggunakan instrumen penelitian, analisis data bersifat kuantitatif/statistik dengan tujuan untuk menguji hipotesis yang telah ditetapkan. Sugiyono (2013:14).

\section{Populasi}

Menurut Sugiyono (2014:80) populasi adalah wilayah generalisasi yang terdiri atas obyek atau subyek yang mempunyai kualitas dan karakteristik tertentu yang ditetapkan oleh peneliti untuk dipelajari dan kemudian ditarik kesimpulannya.

Populasi dalam penelitian ini adalah pegawai tetap di PT. PLN (Persero) Area tanjungpinang dan berdasarkan data yang diperoleh dari pihak manajemen jumlah seluruh pegawai tetap yaitu berjumlah 74 pegawai.

\section{KAJIAN PUSTAKA}

\section{Pelatihan}

Menurut Kamsir (2016:126) pelatihan merupakan proses untuk membentuk dan membekali karyawan dengan menambah keahlian, kemampuan, pengetahuan dan perilakunya. Sedangkan menurut Sedarmayanti (2013:163) pelatihan dan pengembangan merupakan usaha mengurangi atau menghilangkan terjadinya kesenjangan antara kemampuan karyawan dengan yang dikehendaki organisasi.

\section{Disiplin Kerja}

Menurut Sutrisno (2012:97) disiplin kerja merupakan alat yang digunakan para manajer untuk berkomunikasi dengan karyawan agar mereka bersedia untuk mengubah suatu perilaku serta sebagai suatu upaya untuk meningkatkan kesadaran dan kesediaan seseorang menaati semua peraturan perusahaan dan norma-norma sosial yang berlaku.

\section{Budaya Organisasi}

Menurut Sopiah (2008:138) mengatakan bahwa budaya organisasi adalah sekumpulan nilai dan pola prilaku yang dipelajaridimiliki bersama oleh semua anggota organisasi dan diwariskan dari satu generasi ke generasi berikutnya.Sedangkan budaya organisasi menurut Fahmi (2013:47) adalah suatu kebiasaan yang telah berlangsung lama dan dipakai serta diterapkan dalam kehidupan aktivitas kerja sebagai salah satu pendorong untuk meningkatkan kualitas kerja para karyawan dan manajer perusahaan.

\section{HIPOTESIS}

Berdasarkan permasalahan dan kajian pustaka yang telah dikemukakan sebelumya, maka penulis merumuskan hipotesis sebagai berikut :

1. Pelatihan berpengaruh signifikan terhadap komitmen organisasi pegawai PT. PLN (Persero) Area Tanjungpinang.

2. Disiplin Kerja berpengaruh signifikan terhadap komitmen organisasi pegawai PT. PLN (Persero) Area Tanjungpinang. 
3. Budaya Organisasi berpengaruh signifikan terhadap komitmen organisasi pegawai PT. PLN (Persero) Area Tanjungpinang.

4. Pelatihan, Disiplin Kerja, Budaya Organisasi, berpengaruh signifikan terhadap komitmen organisasi pegawai PT. PLN (Persero) Area Tanjungpinang.

\section{METODOGI PENELITIAN}

Metode penelitian ini memakai metode penelitian kuantitatif. Metode penelitian kuantitatif adalah meode penelitian yang berlandaskan pada filsafat positivisme, digunakan untuk meneliti pada populasi atau sampel tertentu, teknik pengambilan sampel pada umumnya dilakukan secara random, pengumpulan data menggunakan instrumen penelitian, analisis data bersifat kuantitatif/statistik dengan tujuan untuk menguji hipotesis yang telah ditetapkan. Sugiyono (2013:14).

\section{Populasi}

Menurut Sugiyono (2014:80) populasi adalah wilayah generalisasi yang terdiri atas obyek atau subyek yang mempunyai kualitas dan karakteristik tertentu yang ditetapkan oleh peneliti untuk dipelajari dan kemudian ditarik kesimpulannya.

Populasi dalam penelitian ini adalah pegawai tetap di PT. PLN (Persero) Area tanjungpinang dan berdasarkan data yang diperoleh dari pihak manajemen jumlah seluruh pegawai tetap yaitu berjumlah 74 pegawai.

Sampel

Sampel dalam penelitian ini menggunakan teknik nonprobability sampling, yaitu teknik pengambilan sampel

yang tidak memberikan peluang/kesempatan yang sama bagi setiap unsur atau anggota populasi untuk dipilih menjadi sampel.

Dalam penelitian ini, teknik yang peneliti gunakan adalah teknik sampling jenuh. Hal ini peneliti lakukan karena sampel yang diambil merupakan jumlah keseluruhan dari populasi yaitu berjumlah 74 sampel.

\section{HASIL PENELITIAN}

\section{Analisis Statistik Deskriptif}

Menurut Sugiyono (2014:147) statistik deskriptif adalah statistik yang digunakan untuk menganalisis data dengan cara

\section{Pengujian Hipotesis}

Tabel 7

Regresi Linear Berganda

\begin{tabular}{|c|c|c|c|c|c|c|}
\hline \multicolumn{7}{|c|}{ Coefficients $^{\mathrm{a}}$} \\
\hline \multirow{2}{*}{\multicolumn{2}{|c|}{ Model }} & \multicolumn{2}{|c|}{$\begin{array}{l}\text { Unstandardized } \\
\text { Coefficients }\end{array}$} & \multirow{2}{*}{\begin{tabular}{|c|}
$\begin{array}{c}\text { Standardiz } \\
\text { ed } \\
\text { Coefficien } \\
\text { ts }\end{array}$ \\
Beta \\
\end{tabular}} & \multirow[b]{2}{*}{$\mathrm{T}$} & \multirow[b]{2}{*}{ Sig. } \\
\hline & & B & $\begin{array}{l}\text { Std. } \\
\text { Error }\end{array}$ & & & \\
\hline \multirow[t]{4}{*}{1} & $\begin{array}{l}\text { (Const } \\
\text { ant) } \\
\end{array}$ & .458 & 1.266 & & .362 & .719 \\
\hline & $\begin{array}{l}\text { Total_ } \\
\text { X1 }\end{array}$ & .739 & .032 & .948 & 23.057 & .000 \\
\hline & $\begin{array}{l}\text { Total } \\
\text { X2 }\end{array}$ & .101 & .038 & .089 & 2.649 & .010 \\
\hline & $\begin{array}{l}\text { Total_ } \\
\text { X3 }\end{array}$ & -.045 & .032 & -.047 & -1.424 & .159 \\
\hline
\end{tabular}

Sumber: data diolah, 2017

Berdasarkan uji regresi linear berganda pada tabel 7 diperoleh persamaan linear berganda sebagai berikut :

$\mathrm{Y}=0,458+0,0739 \mathrm{X} 1+0,101 \mathrm{X} 2-0,045 \mathrm{X} 3+\mathrm{e}$

\section{Hasil Uji T (Parsial)}

Uji $t$ berfungsi untuk mengetahuti pengaruh variabel bebas yang terdapat didalam model secara parsial (terpisah) terhadap variabel terikat, dengan cara ,membandingkan mendeskripsikan atau menggambarkan data yang telah terkumpul sebagaimana adanya tanpa bermaksud membuat kesimpulan yang berlaku untuk umum atau generalisasi. 
Tabel 2

\section{Descriptive Statistics}

\begin{tabular}{|l|c|r|r|r|r|}
\hline \multicolumn{7}{|c|}{ Descriptive Statistics } \\
\hline & N & Min & Max & Mean & Std. Deviation \\
\hline Total_X1 & 74 & 25 & 49 & 39.27 & 6.125 \\
\hline Total_X2 & 74 & 30 & 49 & 41.04 & 4.186 \\
\hline & & & & & \\
\hline Total_X3 & 74 & 28 & 50 & 39.16 & 5.015 \\
\hline Total_Y & 74 & 19 & 40 & 31.86 & 4.775 \\
\hline $\begin{array}{l}\text { Valid N } \\
\text { (listwise) }\end{array}$ & 74 & & & & \\
\hline
\end{tabular}

Sumber: data diolah, 2017

probabilitas dengan taraf signifikan yaitu 5\% atau 0,05 .

\section{Pengaruh Pelatihan terhadap komitmen organisasi}

Berdasarkan hasil pengujian hipotesis (H1) analisis linear berganda variabel Pelatihan memiliki t hitung sebesar 23,057 >1,994 t

tabel dengan taraf signifikansi hasil sebesar $0,000<0,05$, dengan demikian Ha diterima Ho ditolak. Artinya ada pengaruh yang signifikan antara variabel Pelatihan terhadap Komitmen
Organisasi pegawai PT. PLN (Persero) Area Tanjungpinang.

\section{Pengaruh Disiplin Kerja terhadap komitmen organisasi}

Berdasarkan hasil pengujian hipotesis (H2) analisis linear berganda variabel disiplin kerja memiliki t hitung sebebsar $2,649>1,994 \quad \mathrm{t}$ tabel dengan tarafsignifikansi hasil sebesar $0,01<0,05$, dengan demikian Ha diterima Ho ditolak.

Artinya, bahwa ada pengaruh signifikan antara variabel disiplin kerja terhadapkomitmen organisasi pegawai PT. PLN (Persero) Area Tanjungpinang

\section{Pengaruh Budaya Organisasi Terhadap Komitmen Organisasi}

Berdasarkan hasil pengujian hipotesis (H3) analisis linear berganda variabel Budaya Organisasi memiliki t hitung sebesar $-1,424<1,994 \mathrm{t}$ tabel dengan taraf signifikansi hasil sebesar $0,159>0,05$, dengan demikian Ha ditolak Ho diterima. Artinya tidak ada pengaruh signifikan antara variabel Budaya Organisasi terhadap Komitmen Organisasi pegawai PT. PLN (Persero) Area Tanjungpinang.

\begin{tabular}{|c|c|c|c|c|c|c|}
\hline \multicolumn{7}{|c|}{ ANOVA $^{\mathbf{a}}$} \\
\hline \multicolumn{2}{|c|}{ Model } & $\begin{array}{l}\text { Sum of } \\
\text { Squares }\end{array}$ & Df & Mean Square & F & Sig. \\
\hline \multirow[t]{3}{*}{1} & Regression & 1597.411 & 3 & 532.470 & 554.344 & $.000^{\mathrm{b}}$ \\
\hline & Residual & 67.238 & 70 & .961 & & \\
\hline & Total & 1664.649 & 73 & & & \\
\hline \multicolumn{7}{|c|}{ a. Dependent Variable: Total_Y } \\
\hline \multicolumn{7}{|c|}{ a. $\quad$ Predictors: (Constant), Total_X3, Total_X2, Total_X1 } \\
\hline
\end{tabular}

Berdasarkan pada tabel di atas diperoleh nilai $\mathrm{F}$ hitung sebesar 554.344 $>\mathrm{F}$ tabel sebesar 2.74 dan nilai signifikansi sebesar $0,000<0,05$, maka Ho ditolak dan $\mathrm{Ha}$ diterima. Artinya Pelatihan, Disiplin Kerja, dan Budaya Organisasi secara simultan mempunyai pengaruh signifikan terhadap Komitmen Organisasi.

\section{Hasil Uji R ${ }^{2}$ (Determinasi)}


Tabel 10

Hasil Uji $\mathbf{R}^{2}$

\begin{tabular}{|l|c|r|r|r|}
\hline \multicolumn{2}{|l|}{ Model Summary } \\
\hline Model & R & R Square & $\begin{array}{c}\text { Adjusted } \\
\text { R Square }\end{array}$ & $\begin{array}{c}\text { Std. Error } \\
\text { of the } \\
\text { Estimate }\end{array}$ \\
\hline 1 & $.980^{\mathrm{a}}$ & .960 & .958 & .980 \\
\hline $\begin{array}{l}\text { a. Predictors: (Constant), Total_X3, Total_X2, } \\
\text { Total_X1 }\end{array}$ \\
\hline
\end{tabular}

Sumber: data diolah, 2017

Berdasarkan hasil uji koefisien determinasi tabel 4.18 diatas, terlihat bahwa nilai Adjusted R Square sebesar 0,958 atau

95,8\%. Yang berarti bahwa besarnya pengaruh variabel X1 (Pelatihan), X2 ( Disiplin Kerja), dan X3 (Budaya Organisasi) secara serentak terhadap variabel $\mathrm{Y}$ (Komitmen Organisasi) adalah sebesar $95,8 \%$ sedangkan sisanya sebesar $4,2 \%$ dipengaruhi faktor lain yang tidak diteliti.

\section{KESIMPULAN}

Berdasarkan penelitian tentang Pelatihan, Disiplin Kerja, dan Budaya Organisasi terhadap Komitmen Organisasi Pegawai PT. PLN (Persero) Area Tanjungpinang maka diperoleh kesimpulan sebagai berikut :

a. Hasil pengujian secara parsial menunjukkan bahwa variabel pelatihan berpengaruh signifikan yaitu sebesar 23,057 terhadap komitmen organisasi pegawai PT. PLN (Persero) Area Tanjungpinang.

b. Hasil pengujian secara parsial menunjukkan bahwa variabel disiplin kerja berpengaruh signifikan yaitu sebesar 2,649 terhadap komitmen organisasi pegawai PT. PLN (Persero) Area Tanjungpinang.

c. Hasil pengujian secara parsial menunjukkan bahwa variabel budaya organisasi tidak berpengaruh signifikan yaitu sebesar $-1,424$ terhadap komitmen organisasi pegawai PT. PLN (Persero) Area Tanjungpinang.

d. Hasil pengujian secara simultan menunjukkan bahwa pelatihan, disiplin kerja dan budaya organisasi secara bersama-sama berpengaruh terhadap komitmen organisasi pegawai PT. PLN (Persero) Area Tanjungpinang.

\section{SARAN}

Dari hasil penelitian yang dilakukan, maka saran yang diberikan dalam penelitian ini adalah sebagai berikut :

1. Hasil penelitian hendaknya dapat digunakan sebagai bahan pertimbangan bagi PT. PLN (Persero) Area Tanjungpinang dalam meningkatkan Komitmen Organisasi pegawai sehingga lebih baik lagi.

2. Berkaitan dengan penelitian yang telah dilakukan di PT. PLN (Persero) Area Tanjungpinang diharapkan pelatihan dapat diikuti oleh setiap pegawai, agar dapat mengembangkan kemampuan serta keterampilan. Diharapkan disiplin kerja dapat ditingkatkan oleh setiap pegawai agar pekerjaan dapat sesuai dengan rencana yang telah ditentuan.

3. Bagi penelitian yang akan datang, disaran kan untuk memperluas variabel penelitian selain pelatihan, disiplin kerja, dan budaya organisasi pada PT. PLN (Persero) Area Tanjungpinang

\section{DAFTAR PUSTAKA}

Ardana, Komang, dkk, (2009), Perilaku Keorganisasian Edisi 2, Yogyakarta : Graha Ilmu.

Ariyanty,Nel, (2014), Pengaruh Budaya Organisasi Terhadap Kinerja Pegawai. Jurnal Manajemen dan Bisnis, Universitas Muhammadiyah Sumatra Utara. 
Asril,Muchliyanty, (2011), Pengaruh Motivasi dan Disiplin Kerja Terhadap Kinerja Karyawan PT. Reza Fiska Pratama Medan, Universitas Sumatra Utara.

Dalimunthe,Muhammad Faisal, (2012), Pengaruh pendidikan dan pelatihan terhadap peningkatan kinerja karyawan PT. Narasindo Mitra Perdana Medan, Universitas Sumatra Utara.

Fahmi, Irham, (2013), Manajemen Kinerja Teori dan Aplikasi, Bandung : Alfabeta.

Handayani, Siska (2013), Pengaruh Pelatihan dan Aktivitas Manajerial Terhadap Kinerja Pegawai PT. Perkebunan Nusantara II Pabrik Gula Kwala Madu Stabat Sumatra Utara.

Handoko,(2014),Manajemen Personalia dan Sumberdaya Manusia, Yogyakarta : BPFE.

Hartatik, Indah. Puji, (2014), Buku Praktis Mengembangkan SDM, Jogjakarta : Laksana.

Hasibuan, Melayu S.P., (2014), Manajemen Sumber Daya Manusia, Jakarta : PT.Bumi Aksara.

Izati, (2014), Pengaruh budaya organisasi, motovasi dan komunikasi interpersonal terhadap kinerja pegawai puskesmas teluk bintan.

Jackson, Susan E, dkk, (2010), Managing Human Resources (Terjemahan : Benny Prihartanto), Jakarta : Salemba Empat.

Justine dan Purwanto Rahardjo, (2009), Mengelola dan Mengembangkan Sumber Daya Manusia dalam Persaingan Global, Jakarta : Mitra Wacana Media.

Kamsir, (2016), Manajemen Sumber Daya Manusia (Teori dan Praktik), Jakarta :PT Raja Grafindo Persada.
Mangkunegara, Anwar. Prabu, (2014), Perencanaan dan Pengembangan Sumber Daya Manusia, Bandung : PT.Rafika Aditama.

Munandar, Jono M, (2014), Pengantar Manajemen Panduan Komprehensif Pengelolaan Organisasi, Bogor : IPB Press.

Nimpurno,Galih Aryo, (2015), Jurnal, Pengaruh Disiplin Kerja dan Gaya Kepemimpinan Terhadap Kinerja Karyawan UD. Pustaka Pelajar Yogyakarta.

Oemar, Yohana (2013), Jurnal Aplikasi Manajemen, Pengaruh Budaya Organisasi, Kemampuan Kerja dan Komitmen Organisasi Terhadap Organizational Citizenship Behavior (OCB) Pegawai BAPPEDA Kota Pekanbaru, Universitas Riau Pekanbaru.

Ramadhan,Ilham, (2009), Jurnal, Pengaruh Program Pendidikan dan Pelatihan terhadap produktivitas Kerja Karyawan Pada KUD Trisula di Kabupaten Majalengka.

Ririen, (2012), Pengaruh Budaya Organisasi dan Komitmen terhadap Kinerja Karyawan PT. Panen Raya.

Sedarmayanti, (2013), Manajemen Sumber Daya Manusia, Reformasi Birokrasi, dan Manajemen Pegawai Negeri Sipil, Bandung : PT. Refika Aditama.

Siagian, Sondang P, (2014), Manajemen Sumber Daya Manusia, Jakarta : PT. Bumi Aksara.

Sopiah, (2008), Perilaku Organisasional, Yogyakarta : C.V Andi Offset (Penerbit Andi).

Sudarsono,Dedy Syahputra, (2015), Pengaruh lingkungan kerja, kompetensi, dan disiplin kerja, terhadap kinerja pada 
kantor badan pertanahan nasional kota Medan, Universitas Sumatra Utara.

Sugiyono, (2014), Metode Penelitian Kuantitatif, Kualitatif, dan R\&D, Bandung : Alfabeta.

Sulistio,Sylvia, (2016), Pengaruh disiplin kerja, pelatihan kerja, lingkungan kerja dan motivasi kerja terhadap produktivitas kerja pada PD. BPR Bintan Tanjunguban.

Sutrisno, Edy, (2015), Manajemen Sumber Daya Manusia, Jakarta : Prenada Media Goup.

Supatmi,Mamik Eko, dkk Jurnal, Pengaruh Pelatihan, Kompensasi Terhadap kepuasan Kerja Karyawan dan Kinerja Karyawan, Jurnal, Fakultas Ilmu Administrasi Universitas Brawijaya Malang.

Uus, Md Fadli, dkk, Jurnal Manajemen, Pengaruh Kompetensi Karyawan Terhadap Komitmen Kerja Pada PT. PLN (Persero) Rayon Rengasdengklok.

Wibowo, Agung Edy, (2012), Aplikasi Praktis SPSS Dalam Penelitian, Yogyakarta : Gava Media.

Wibowo, (2016), Manajemen Kinerja, Jakarta :PT. Raja Grafindo Pers 